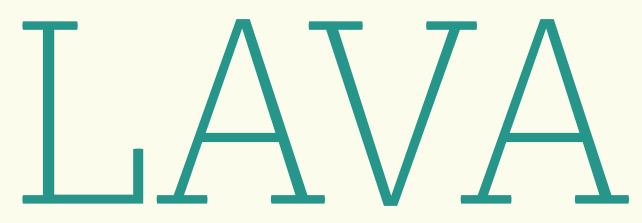

Matéria liquida lançada pelos vulcões.

Torrente, enxurrada, curso. 



\title{
DE SHANDY A LÍSIAS: UMA ANÁLISE DO JOGO ENTRE AUTOR, NARRADOR E LEITOR
}

\author{
- WILLIAN VIEIRA
}

\section{RESUMO}

O artigo a seguir propõe uma comparação crítico-teórica entre The Life and Opinions of Tristam Shandy, Gentleman, de Laurence Sterne e Divórcio, de Ricardo Lísias. Busca-se aproximar o romance do século 18 em primeira pessoa, visto por muitos críticos como sátira genérica com elementos autobiográficos, do romance autoficcional contemporâneo, que repete e exacerba tais elementos e mecanismos ao infinito, a partir da análise do pacto de leitura e da suspensão estatutária entre discursos real e ficcional.

Palavras-chave: autoficção, estatuto textual, pacto de leitura, performance

\section{ABSTRACT}

This article proposes a theoretical and critical comparison of The Life and Opinions of Tristam Shandy, Gentleman, by Laurence Sterne and Divórcio, by Ricardo Lísias. It proposes an approximation of the first-person Eighteenth century romance, seen by many critics as a genre satire filled with autobiographical elements, and its contemporary autofictional counterpart, that repeats and exacerbates many mechanisms and elements of the former. The analysis is centered on the reading pact and the suspension of the status of the text.

Keywords: Autofiction, ficcional status, reading pact, performance
A proximar, mesmo que a título heurístico, Laurence Sterne e Ricar- do Lísias, ou Tristam Shandy, narrador de The Life and Opinions of Tristam Shandy, Gentleman ${ }^{1}$, e Ricardo Lísias, o narrador que encerra a homonímia traiçoeira de Divórcio, pareceria a qualquer crítico o (perigoso) paroxismo de um exercício tipicamente shandyano de livre 
associação intertextual em seu caráter mais satírico: o de tudo comparar para nada dizer. O abismo espaço-temporal, histórico e estético, soa intransponível. Mas eis que a voz insidiosa do narrador de Sterne sugere a possibilidade de estabelecer um campo de problemas teórico-críticos entre as obras como frutífera. E a fortuna comparatista de TS, generosa, afiança a tese de que tudo o que de Shandy se aproxima ganha outra verdade.

Afinal, Sterne criou uma (meta)ficção travestida de autobiografia que remete à sua própria biografia ${ }^{2}$, levantando, por meio do narrador que a todo tempo demarca e embaralha a natureza estatutária da obra, a questão das fronteiras entre real e ficcional, biografia e imaginação, vida e literatura, nesse complexo gênero do romance em primeira pessoa que guarda semelhanças identificáveis ao leitor - inquirido a decidir, estética e eticamente, a chave de leitura. Por isso, creio que revisitar TS para analisar um romance recente que retoma tais questões para exacerbá-las ao infinito, tomando a literatura como performance social e libelo crítico da função estética do campo e adicionando questionamentos de cunho ético e político, uma possibilidade potente.

Antes, algumas definições devem ser esclarecidas: por exemplo, as de autobiografia e autoficção ${ }^{3}$. O consenso acadêmico entende os termos como distintos ao menos em alguns pontos: seguindo Ricouer (2012), na autobiografia, como na História, haveria ao menos a intenção do autor ${ }^{4}$ em narrar a verdade de sua vida como essa transcorreu, a despeito da impossibilidade de fundir sujeitos múltiplos no tempo e espaço em uma narrativa coesa cujo personagem que narra tenha uma identidade única. Na autoficção, diz Gasparini (2007) o trabalho imaginativo não enfrentaria limites estéticos ou éticos (em relação à verdade da narrativa): a biografia

[2] Vide o personagem do pastor Yorick, cujos sermões adentram TS, como veremos em seguida.

[3] O termo autoficção surgiu na França em 1977 com Fils, de Serge Doubrovsky e se tornou consensual na academia, imprensa e mercado editorial para definir certos romances calcados no cruzamento deliberado entre realidade e ficção. Na contracapa do volume, Doubrovsky a definia assim: "fictions d'événements et de faits strictement réels". Desde então, o conceito ganhou outras definições. Galle (2015), define-a assim: "A autoficção seria uma figura semiótica, um signo pelo qual o autor implícito opera um jogo metaficcional que transborda a ficção e tem impacto ambíguo na imagem do autor" (p. 162).

[4] Tal intenção só é aceita na análise como percebida pelo leitor. A mediação da leitura proporciona, diz Ricoeur, a interação entre o mundo do texto e o do leitor. Essa refiguração partiria do mundo do texto para um mundo outro, que "se abre diante de si e oferece à apropriação critica do leitor" (tomo II, p. 174). Ler algo que jaz suspenso entre um discurso de verdade e outro imaginativo (logo, ficcional), seria uma "experiência virtual do ser no mundo proposta pelo texto" (idem), que permitiria uma "transcendência imanente" (idem). Concordo com Ricoeur: existe um mundo do texto que é acessado pelo leitor e projetado em seu próprio mundo (o mundo real no senso comum), refigurando uma realidade na outra a partir de um arcabouço próprio (um horizonte de expectativas, como diria Jauss). É nessa dialética da representação do discurso de verdade no mundo real que se encontra a questão literária proposta. 
seria apenas ponto de partida; a chegada seria a ficção, e seu espaço, o debate de tais limites, de tal paroxismo.

Do ponto de vista da estrutura da narrativa, porém, a diferença some $^{5}$. E ela, se não inexistia totalmente na época de Sterne (o século 18 inglês), era então entendida como problema diferente. Daí o interesse em aproximar uma ficção que parodia o gênero autobiográfico ao metaficcionalizá-lo via wit, de uma ficção que faz operação semelhante (questionando-se como possibilidade formal, ética e política) agindo também como confissão-libelo - ou seja, sem abrir mão de sua incerteza estatutária, mas, ao contrário, dela se alimentando para suspender seu estatuto, questionando, por fim, a natureza ontológica do romance em primeira pessoa. Interessa-me analisar como, para o leitor, um narrador que diz eu e conta sua história, comentando a obra em curso e a vida a ela ligada, ganha, no ato da leitura, vida própria, torna-se uma entidade supranarrativa indissociável (num e noutro romance, de forma textualmente similar, ainda que com efeitos de leitura distintos dado o contexto de recepção) e questionar como as especificidades da autoficção levam o jogo ao paroxismo.

Sem incorrer (ao menos deliberadamente) no artifício shandyano da digressão como crítica à impossibilidade de representar linearmente uma vida, ou, no caso, de alcançar uma suposta verdade, creio valer a pena pontuar outra comparação. Pois outros já fizeram tal exercício comparativo com resultados ricos. Vejamos apenas um exemplo. PoRTER (1976) desenvolve uma análise comparativa entre TS e Henry Brulard, espécie de autobiografia de Stendhal narrada por um protagonista heterônimo, na qual emergem vários dos pontos dos quais parti para pensar a autoficção em comparação a TS. Entre eles, a materialidade física do livro trazida à tona, as referências à existência física do autor (como personagem ou não) e esse presente contínuo que advém do gênero autobiográfico, dado seu caráter auto-reflexivo e seu lugar de enunciação.

O problema que enfrenta um autor quando toma da pena e começa a escrever, trazido temática e formalmente para o texto atual, é das primeiras questões levantadas por Sterne (ainda que não inventada por ele ${ }^{6}$ ) que ganharão vida na autoficção com requintes estatutários

[5] Tal discussão sobre a especificidade textual da autobiografia e da autoficção já foi esmiuçada por muitos críticos, de Cohn e Genette a Lejeune e de Mann, passando por Compagnon e Gasparini.

[6] Wayne Booth mostrou como a década de 1750, na qual Sterne começou a publicar TS, era repleta de autores tentando alcançar uma forma de narração auto-consciente com a figura cômica de um autor preocupado com os processos da escrita (RICKs, 2013, p. xvi). 
outros como tema central. Tematicamente por que, como Sterne fará com maestria, o processo de escrita do livro enquanto obra física objetiva (this book, this drama, etc.), que é escrito, editado, publicado e criticado, ganha sua própria história ao longo dos volumes ${ }^{7}$. Como veremos, as referências não só ao ato de criação da obra no tempo e no espaço mas à sua publicação, que parecem surgir em Cervantes e ganhar forma acabada em TS tornar-se-ão um topos singular da autoficção (num caso graças à divisão em volumes; no outro, graças aos epitextos que a alimentam).

Formalmente, porque a materialidade do livro, em oposição à virtualidade da narrativa, é tema central em TS (assim como na autoficção), por exemplo quando Shandy lembra o leitor que o trecho poderia ter sido escrito de forma diferente - "and in the next edition care shall be taken that this chapter be expunged" (p. 16) - ou quando capítulos são deixados em branco (vide pp. 565-666). Sterne faz do ir e vir que rompe a linearidade da obra sendo escrita ${ }^{8}$ não só uma sátira que parodia o gênero autobiográfico em voga, mas também um questionamento da natureza ontológica do romance, ao exibir a "caixa de ferramentas" do escritor que busca representar uma vida pela via literária.

O eterno presente da obra sendo escrita (e, acrescento, a sensação desse presente perene na leitura), o que pareceria a princípio uma espécie de paradoxo em relação ao cunho confessional-autobiográfico do gênero em questão - mas que revela a natureza intrinsecamente artificial de qualquer cronologia linear, dado o lugar fixo da enunciação de uma narrativa auto-reflexiva em primeira pessoa -, é outro bom ponto levantado por Porter. No caso de TS, porque a obra avança propositalmente pouquíssimo no tempo e no espaço. Para Porter, a autobiografia (strictu sensu) como gênero parece, aliás, apenas cumprir o papel, em TS, de permitir a vazão do wit sterniano: a vida dá margem às opiniões e essas aos julgamentos ${ }^{9}$. A comparação com Sthendal lhe parece cabal:

[7] Com base na teorização genettiana, Williams (1990) verá TS como uma "narrativa da narrativa" (p. 1033), uma história sobre o ato de narrar uma história, com reflexividade infinita.

[8] O que dizer do efeito das linhas que representariam graficamente sua estrutura narrativa (pp. 425-426)?

[9] O que faz alguns críticos classificarem TS não como autobiografia ficcional, mas como a biografia ficcional da família Shandy contada por um narrador satírico sem limites diegéticos ou de consciência narrativa que não é o protagonista do plot biográfico, mas da narrativa metaficcional alavancada por ele. 
The problem is both "authors" are obliged to narrate not from the perspective of a specific moment in time but from a present of narration that is itself more or less protracted several years in the case of Sterne, several months in the case of Stendhal. The result in both works is not that satisfying periodicity of infancy, youth, maturity and age, but fragmentation and discontinuity. The raw materials of both a real and an imagined life are allowed to frustrate the aesthetic impulse to fashion them into plot (p. 1264).

Com o narrador conduzindo a narrativa de forma pessoal, abrindo digressões a granel, mas sempre explicando ao leitor os porquês do tortuoso caminho do texto, TS torna-se uma grande história oral comen$\operatorname{tada}^{10}$, espécie de compêndio de memórias e wit amarradas sob a égide de um gênero que é o tempo todo repensado e criticado ${ }^{11}$.

A aproximação mais importante feita por Porter, e que tanta luz pode lançar ao presente trabalho, porém, é a demarcação da existência física, corpórea, do narrador (e suposto autor) na obra ${ }^{12}$. Em TS, o narrador diz quando e onde está escrevendo o capítulo que o leitor está lendo (vide a p. 42, onde diz: I am now writing this book for the edification of the world, - which is March 9, ou a p. 212, onde diz: "in that period at least of it, which I have sat down to write the story of' $)^{13}$. Sterne (ou Shandy), não só conversa com seu leitor numa atmosfera de story telling ${ }^{14}$, ora avisando o tipo de narrativa que segue, ora pregando peças e por elas se desculpando, como anuncia o tipo de leitor que fruirá bem sua obra: "for I declare before hand, 'tis wrote only for the curious and inquisitive” (p. 8).

[10] GenETTE (1980) chamará esse caráter metadiegético da narração shandyana de "metalepsis", afirmando, sobre TS: "Sterne pushed the thing so far as to entreat the intervention of the reader, whom he beseeched to close the door or help Mr. Shandy get back to his bed" (p. 234).

[11] Como veremos, no caso de Lísias (narrador), como é praxe na autoficção, uma história, o divórcio, precisa ser contada (quem o diz é o narrador e o paratexto) para que sua vida retome o sentido, mas a memória de sua vida (a mesma do narrador de outros livros, como O Céu dos Suicidas e, como veremos, também do autor que assina a obra, como demonstram epitextos a ele ligados) interrompe a linearidade da história todo o tempo, dando ao livro um caráter genérico de autobiografia indelével, intra e extra-obra.

[12] Que, no caso de Lísias, como veremos, ganhará um caráter de presença também do autor.

[13] Assim, como diz Porter: "Instead of remote and masterful storytellers, we have in both cases supposed authors who reveal their presence and the circumstances, both physical and intellectual, of their decision-making. An author, they remind their readers, is a man who sits at a table in order to write or who paces up and down in self-doubt" (p. 1262).

[14] Como diz Shandy em dado momento: "Writing, when properly managed, (as you may be sure I think mine is) is but a different name for conversation" (p. 96). 
E esse leitor, em 1759, recebe TS num contexto de ambiguidade estatutária, já parte do romance inglês em formação ${ }^{15}$.

Uma última digressão merece espaço: pensar com Davis e Defoe sobre o estatuto de ficcionalidade do romance inglês do século 18. Para o crítico, o distanciamento anunciado por Defoe de seu narrador no prefácio de Roxana seria um princípio "novelístico" novo que o separaria, por exemplo, de Dom Quixote. Exemplos de intrusão da realidade na ficção como técnica reconhecível pelo leitor fariam parte do mesmo arcabouço, num contexto de recepção onde o gênero ainda se encontra imbuído da indistinção entre fato e ficção ${ }^{16}$. Tal artifício seria inaugurado por um frame reverso, por exemplo quando Defoe diz no prefácio que a narrativa não é ficcional, mas factual, ambiguidade que perseguirá o leitor até o fim - visto que o frame inicial (isso é verdade) é seguido de outro oposto (isso é ficção), o que ele chama de "suspensão da suspensão da descrença” (p. 23): seja pelo prefácio, pela estrutura narrativa, ou por ambos, o leitor é levado à dúvida estatutária, alimentada ainda por um contexto cultural no qual ficção e verdade não são tão separadas. Assim, no "processo de fabricação" da obra, o leitor é parte cabal: é quem atribui ao discurso sua relação com o mundo real.

Afinal, como demonstra Davis em sua teorização das baladas como origem do romance na Inglaterra, alguma noção de verdade e ficção, de real ou ficcional, existia, claro, nos séculos 17 e 18, mas não atrelada à noção de gênero. Ou seja, assim como as baladas se vendiam um século antes como verdadeiras, ainda que pudessem ser lidas como causos imaginados pelos leitores de então, os romances não eram recebidos como sendo plenamente ficcionais apenas por serem romances (p. 67). Tese que se coaduna com a "crise epistemológica" que McKeon (1985) enxerga no momento de ascensão do romance na Inglaterra da época - ou seja, uma crise em relação à autoridade identificada nos gêneros impressos em

[15] O que vai ao encontro das noções de "aura conceitual" e "contexto presentacional" que Davis (1983) vê como fundamentais para a "pré-estrutura” da obra (p. 12). Davis focará em Daniel Defoe para afirmar que o romance surge como gênero do hiato fenomenológico e epistemológico entre ficção e realidade.

[16] Como veremos, a autoficção, como o exemplo de Divórcio dá conta, retoma a mesma discussão, exacerbando-a, rompendo os limites do esperado, do sabido e do aceitável. 
erupção, e nas "atitudes em relação a como dizer a verdade em narrativas" entre o fim do século 17 e o começo do 18 (p. 161) ${ }^{17}$.

Davis não explora a noção de pacto que, desde Lejeune (1975), permeia o debate sobre autobiografia e autoficção. Mas ela é central para discutir recepção e leitura. Ao investigar como o leitor recebe o discurso de verdade da autobiografia, Galle (2011) afirma que ela não é um gênero mais "contratual" que qualquer outro ${ }^{18}$. Mas dado um contexto cultural como o do século 18, no qual verdade e ficção se permeiam mutuamente em discursos impressos, onde baladas, panfletos e news de todo tipo atestam uma veracidade inexistente, e sobretudo em romances onde tanto os paratextos como a estrutura formal da narrativa depõem a favor da confusão estatutária - e quando a noção de ficção não está ligada indissociavelmente a um gênero -, o pacto de leitura que orientará a fruição da obra fica abalado, marcado pela ambiguidade e pela dúvida ${ }^{19}$.

Vide Defoe e Robinson Crusoe. Para Davis (p. 157), apesar de o prefácio seguir a convenção literária da época, de atestar sua suposta veracidade, para o leitor, o estatuto da obra seguia dúbio, oscilando entre história real e construção ficcional. E, pela primeira vez, um romance mereceu um ataque de um crítico justamente por se vender como não-ficcional (idem). "Mestre da confusão", Defoe teria adentrado a seara da alegoria (p. 158), numa época em que o romance se erguia sobre uma base frágil, que não separava verdade e ficção na feitura e na leitura do gênero em formação. "It is this element of doubt that Defoe will use for his remaining novels. (...)

[17] Como afirma Mckeon (id.): "By modern standards, the most pressing problem raised by such usage is the absence of any will to distinguish consistently between 'history' and 'literature', 'fact' and 'fiction"'. Prova-o a organização taxonômica dos catálogos bibliográficos, nos quais "a preocupação moderna" (p. 163) em "descriminar entre factual e ficcional" (idem) inexistia. Ao mesmo tempo, crescia, com certo "empiricismo ingênuo", alimentado por novas noções de uma epistemologia do discurso de verdade a partir da disseminação da imprensa e da importância da experiência pessoal e do registro das vidas idealizadas como "histórias verdadeiras" (p. 167) a partir da Reforma, o descrédito e a atribuição pejorativa ao termo romanesco (romance), tido como "mentira e ficcionalização" (p. 163), movimento que geraria sua própria antítese e crítica com o ceticismo radical em romances como os de Swift e Sterne.

[18] "A comunicação em geral consiste em atos ilocutivos que os emissores realizam com elementos semióticos para provocar uma determinada reação nos receptores" (p. 73), afirma. "Para que o ato seja bem-sucedido, é necessário que os dois se entendam sobre o significado dos sinais" (pp. 73-74). Esse entendimento é apenas tácito, implícito, atrelado a ponderações de ordem genérica, culturais. "O modelo indica como o texto deve ser entendido, e os leitores que dispõem da mesma bagagem cultural que o autor vão entendê-lo dessa maneira" (p. 74).

[19] Assim, a decisão sobre a chave de leitura cabe ao leitor, a seu contexto próprio - como diria Ricoeur, à prefiguração (ou, como diria Davis à "pré-estrutura") e à refiguração posterior (ou mimese III). 
The ambivalence fills the first two frames - neither the reader nor the editor ${ }^{20}$ knows whether the work is true or false" (p. 162).

"Editor" de autobiografias de personagens imaginários, Defoe, assim como depois Sterne, fará uso da ambivalência do estatuto ficcional de seus romances - usando o "frame da dúvida" (p. 163) para atrair o público leitor, a ponto de, no prefácio de Moll Flanders, deixar a cargo desse a tarefa de fruir ir a narrativa "just as he pleases" (idem)21. A conclusão de Davis é que os romances (no século 18 inglês), são "obras enquadradas" cuja "atitude em relação a fato e ficção é constutivamente ambivalente" (p. 212). Para autores como Defoe, que estavam lançando as bases do gênero, era preciso justificar um novo relacionamento entre língua, texto e experiência vivida.

Davis ignora Sterne: seu objetivo é a origem do romance e TS viria décadas depois. Mas a partir dessa discussão sobre fato e ficção no século 18 inglês, podemos retomar nossa narrativa e elencar ainda outros elementos em TS que vão ao encontro da definição de um estatuto ambíguo do romance no século 18 inglês, que veremos repetir-se nos romances contemporâneos sob o rótulo de autoficção. Um deles é o enxerto de discursos reais no texto do romance - textos do próprio autor ${ }^{22}$. Sterne publicou, desde 1960, uma série de sermões (The Sermons of Mr. Yorick (TSMY), dos quais trechos foram inseridos em TS, atribuídos ao mesmo Yorick, seu alter-ego tardio ${ }^{23}$. Por exemplo, o sermão que cai do livro sobre fortificações de Toby no segundo volume (pp. 108-125), foi inicialmente proferido por Sterne em 29 de julho de 1750 e logo publicado como panfleto - ou seja, 10 anos antes da publicação em TS e logo em

[20] As notas de rodapé, onde o suposto autor corrige o suposto narrador, funcionam durante a leitura da mesma forma que a figura do editor, dando um passo atrás no lugar de enunciação que torna o texto ambíguo em termos de estatuto ficcional. Vide o exemplo da nota da p. 153.

[21] Aos poucos, o autor migra de uma asserção de verdade intrínseca ao romance para a ambivalência absoluta. Diz Davis: "One senses that Defoe has, unwillingly and under fire, moved from a pure assertion of veracity $t$ a highly contextualized and qualified one. In this movement, he has responded a cultural demand for a more explicit definition of a work's factuality or fictionality" (p. 166).

[22] Uso aqui a definição de intertextualidade decantada pelo trabalho exaustivo de SAMOYAULt (2010), para pensar, por exemplo, o uso de fragmentos textuais outros, "diretamente emprestados do real", que funcionam como empréstimos que rompem o caráter ficcional do texto e levam o leitor ao mundo real. Como bem define a autora: "En introduisant des bribes ou des fragments d'objets étrangers à l'art, directement empruntés au réel, il s'agit de coller la vie dans l'art, de la faire apparaître sans transformation et de brouiller ainsi les frontières entre l'art, la fiction et la réalité" (p. 25).

[23] Como afirma Hunter (1971), a respeito da intertextualidade no sermão: "One of his accomplishments is to emphasize the unusual connection of Tristram Shandy with Sterne himself and to toy with both the affirmation and denial of Yorick as Sterne" (p. 136). 
TSMY ${ }^{24}$. Além de intertextos do tipo, há a menção e a participação de figuras reais na história, como é o caso de Garrick (p. 163), famoso ator da época e amigo de Sterne.

Outro elemento (ignorado pela análise de Porter) é o autocomentário. Além da materialidade objetiva escancarada da obra (Shandy se refere ao próprio livro como algo que o leitor carrega, abre e fecha como quer), o narrador comenta sua feitura, discutindo com o leitor a própria condição ontológica do romance sendo produzido. Por exemplo, quando efetua uma de suas primeiras grandes digressões, ao narrar os amores de tio Toby, o narrador decide defender a estrutura narrativa do livro:

By this contrivance the machinery of my work is of a species by itself; two contrary motions are introduced into it, and reconciled, which were thought to be at variance with each other. In a word, my work is digressive, and it is progressive too, - and at the same time (pp. 63-64).

Isso sem falar dos capítulos que o narrador cria na presença do leitor $^{25}$ e na relação com os críticos da obra ${ }^{26}$ (respondendo às críticas dos volumes anteriores), um diálogo entre criação e recepção que expande a existência do romance para uma dialética ficção-realidade ad infinitum; o fato de surgir, na página 174, um "prefácio" escrito pelo narrador, misto de desagravo, desabafo, defesa e autocomentário; a ausência da autoria especificada (no fac-símile da capa original de cada volume, não figura o nome do autor), o que colabora para o efeito de suspensão estatutária; a negação, dentro do romance, da dimensão farsesca da narrativa ${ }^{27}$; e o fato de o narrador se identificar como escritor (ou biographical writer, p.256), que, inclusive, lamenta os livros encalhados (p. 495) e a profissão, "a poor devil's writing for daily bread)" (p. 263), e classifica "a vida de um escritor" como guerra (p. 337), o que contribui para a construção de uma

[24] Como diz Sinding (2010), Sterne foi considerado imoral por mesclar dois gêneros de discurso, o religioso e o prosaico (p. 123). A questão problemática, parece, não era misturar verdade e ficção.

[25] O que dizer do "capítulo sobre capítulos mencionado na p. 252, da conclusão de que cada dia que gasta escrevendo mais acumula tarefas do que as finaliza (p. 257) ou quando defende-se dizendo que nunca se inspirou no rei para criar seu personagem de Toby?

[26] Vide o excerto a seguir: "And what of this new book the whole world makes such a rout about it? (...) Of all the cants which are canted in this canting world, - though the cant of hypocrites may be the worst, - the cant of criticism is the most tormenting!" (p. 164)

[27] No quinto volume, assim começa o capítulo XV, deixando ao leitor a árdua tarefa de digerir a afirmação de veracidade do narrador: "Had this volume been a farce, which, unless every one's life and opinions are to be looked upon as a farce as well as mine, I see no reason to suppose - the last chapter, Sir, had finished the first act of it, and then this chapter must have set off thus" (pp. 354-355). 
instância narrativa com pés fincados na realidade do leitor ${ }^{28}$.

Tais elementos, juntos, dão ao leitor a sensação de incerteza quanto ao estatuto do texto, sobretudo dado que a distinção entre fato e realidade era tênue na época e que o próprio romance como gênero tornara-se o espaço desse debate. $O$ pacto de leitura estabelecido entre TS e seu leitor é o de uma fruição ambígua, entre um discurso de verdade que se questiona como tal (via autocomentário) e uma ficção permeada de intertextos e uma voz nitidamente real, a de Shandy, mas também de Yorick, de Sterne. O leitor (sobretudo aquele que tem como hobby-horse a literatura) tem em mãos uma obra que sustenta qualquer visada possível. Desde que, como pede Shandy, saiba ler.

Do século 18, voltamos ao 21. Aceito o deliberado anacronismo da proposta (a comparação não visa genealogias, mas um exercício heurístico sobre o efeito de leitura de narrativas de estatuto ficcional suspenso em contextos culturais específicos), analisarei a autoficção contemporânea a partir do livro de Lísias ${ }^{29}$ - para tentar compreender como tal gênero atualiza e leva ao extremo expedientes inaugurados e sistematizados pelo romance inglês do século 18, tão bem decantados na obra de Sterne.

Passados em revista os elementos formais e temáticos que alimentavam a suspensão estatutária do discurso de romances como TS ou os de Dafoe, a pergunta que se coloca é a seguinte: quando o nome que encima a capa do livro sob a rubrica romance/ficção surge no texto em primeira pessoa, assim como em textos paralelos a ele ligados e que mesclam indissociavelmente vida do autor e vida do narrador, canalizando para o real/biográfico o que a dita ficção realista costumava manter na prateleira do estritamente imaginário (ainda que, em termos de estruturação narrativa sejam textos realistas, com modos de narrar, utilização de frames e uso da História similares), que tipo de operação estética e ética se dá? O que, na sequência, dará vazão à segunda e definitiva questão: não seria tal indefinição estatutária um novo frame da literatura contemporânea, constitutivo de um horizonte de expectativa novo, ainda afiliado à hegemonia da experiência subjetiva do pós-guerra, mas cada vez mais dado aos meandros da indefinição autoral como pressuposto de um jogo de fruição literário?

[28] Leitor que, segundo Patteson (apud Morini, 2010), lê tais romances sob o prisma da "busca de determinância" (p. 342), uma "determinância semântica" da voz do autor na narração, de sua autoridade.

[29] Que, como veremos, funciona quase como um guia analítico para analisar o gênero 
A dimensão narrativa do eu surge na sétima palavra de Divórcio (2013, p. 7), na conjugação do verbo achar (achei que tivesse morrido). A 12a é corpo (meu corpo). O narrador, em primeira pessoa, descreve um estado de angústia, perda de sentido e quase-morte onde se sente sem pele. É o relato de uma experiência, em algum âmbito, real. Estão aqui as metáforas patemicamente fortes do processo de viver e verter tal vida em escrita íntima: o corpo, a falta de pele e de ar, o desafio do corpo fraco na superação pela corrida, a morte. Oferecido em primeira pessoa por um narrador-protagonista que pontua a cada frase o que sente, o que pretende fazer para deixar de senti-lo e como o fará pela via literária, o texto, localizado no tempo e no espaço, mesmo quando apela para as memórias do narrador, com suas frases curtas e vocábulos simples, é de assimilação natural. A empatia é imediata. Explicando ao leitor o tempo inteiro sua situação psíquica e seu projeto para a vida e para o livro, o narrador ganha um aliado ${ }^{30}$.

Assim, Divórcio poderia ser apenas mais um romance em primeira pessoa. Até que, na p. 11, em itálico, surge um trecho de diário ${ }^{31}$, com o nome Ricardo: como logo se saberá (se não se soube antes pela contracapa), é o diário da ex-mulher do narrador.

NY, 14 de julho de 2011 (no hotel Riverside):

Apesar de andar muito, o Ricardo é legal. Ele é uma boa companhia: é engraçado e de vez em quando inteligente. É que as vezes (sic) nos intervalos das caminhadas que ele quer fazer o tempo inteiro ele diz coisas inteligentes. Mas eu também não entendo: ele se recusa a ver uma peça da Broadway! Os grandes autores do mundo passaram pela Broadway, mas não adianta dizer isso. Ele não dá atenção. Mas a viagem está servindo pra me mostrar que apesar disso eu casei com o cara certo pra mim. Só que apaixonada eu não estou (pp. 10-11).

Os índices de referencialidade se seguem. Na p. 13, o narrador se revela escritor ("Comecei a escrever porque”...). Duas páginas depois,

[30] Lísias (o narrador) está longe de compartilhar o wit de Shandy, e tampouco "conversa" diretamente com o leitor. Mas, como se verá, explica a ele o tempo todo sua empreitada literária, que, como no caso de TS, é permeada pela vida vivida em paralelo.

[31] Tais passagens italizadas se intercalarão ao texto em primeira pessoa do narrador até o fim do livro. 
escreve: "Eu acabara de escrever um SMS chamando minha mulher de puta quando, na metade de uma frase autobiográfica, achei que estava vivendo um dos meus contos. Com certeza eu assinaria essa história" (p. 15). Menciona então um dos personagens de Lísias, (Damião) ${ }^{32}$ e emenda: "Apaixonei-me pela minha ex-mulher no dia do lançamento de O Livro dos Mandarins. Não aconteceu nada: ela não escreveu esse diário e não cobriu o Festival de Cannes de 2011 para um jornal. É só um conto (idem)". E, poucas linhas depois: "Só pode ser ficção. No meu último romance, $O$ céu dos suicidas, o narrador enlouquece e sai andando. Agora, fiquei louco e estou vivendo minhas personagens" (idem) ${ }^{33}$.

Ler Divórcio é percorrer o arcabouço da autoficção contemporânea. Lísias, em nove páginas, entrega as chaves para compreender e entrar em seu jogo literário. Estão aqui as referências ao nome do autor/narrador/personagem, o caso mais tradicional da homonímia autoficcional; à profissão de escritor ${ }^{34}$; às obras ficcionais publicadas pelo autor real (as mesmas figuram na orelha do livro), aqui atribuídas ao narrador-personagem; à veracidade dos nomes ${ }^{35}$; ao gênero em si, fixado entre os termos "nota autobiográfica", "conto", "ficção", "diário"... e mesmo a distinção do registro tipográfico, com trechos narrados por uma outra pessoa, a ex-mulher, italizados, enquanto a voz protagonista da história segue em fonte normal. Isso sem mencionar os paratextos e seu papel para a indecibilidade estatutária, como se verá em seguida.

Assim, a princípio, estar-se-ia no mesmo terreno de ambiguidades pactuais do leitor de Defoe frente ao prefácio de Robinson Crusoe, ou do leitor de TS frente aos sermões de Yorick e ao narrador verborrágico do livro em primeira pessoa que o explica enquanto o escreve e comenta seu até seu impacto e crítica. Afinal, como se viu até aqui com TS e seus contemporâneos, ficção e realidade embaralhadas é tema e ganha forma na literatura ao menos desde então. $\mathrm{O}$ mesmo vale para a figura do autor reconhecível no narrador. Mas a noção de um autor-narrador-personagem

[32] Na p. 36, "meu amigo André" é mencionado ao falar de morte. Ele é o personagem de O Céu dos Suicidas. O personagem reaparecerá outras tantas vezes ao longo do romance.

[33] Tais obras, atribuídas aqui ao narrador, são da autoria de Ricardo Lísias, autor. A homonímia se fecha.

[34] Na página 60, o narrador se confessará "professor de gramática de língua portuguesa em um centro universitário especializado em tecnologia", também ocupação do autor.

[35] A ex-mulher não ganha um nome, pois o epíteto é mantido, o que ocorre com outros personagens; os amigos cujos nomes aparecem o fazem com nomes reais; personagens sem epíteto são referidos por [X]. 
de biografia rastreável projetado dentro e fora do texto sob a égide de um estatuto eternamente suspenso parece específica. Tal literatura ganhou corpo, como prática e crítica, na França do século 20. E o contexto cultural, que para Davis define a recepção de tais ambiguidades, é outro.

O leitor de Divórcio (se souber ler, como dizia Shandy), tem atrás de si não só todo o realismo e a discussão sobre a representação em literatura, como uma imensa biblioteca de obras que problematizam o estatuto ficcional do literário ${ }^{36}$. Seu horizonte de expectativas frente a um romance é amplo $^{37}$. Ele sabe questionar incongruências em uma autobiografia e pensar sua natureza ontologicamente inviável como discurso de verdade. Divórcio, porém, é o exemplo cabal de um romance construído com toda a tecnologia disponível para complexificar a leitura. Seu pacto é mais complexo, posto que sua indecibilidade é permeada por outros discursos disponíveis, que vão além do biográfico ${ }^{38}$. Em Divórcio, o pacto é "paradoxal" (p. 108) $)^{39}$. O estatuto final do texto e, logo, a natureza específica do pacto, seguem embaralhados por sinais de ordem diversa, como as referências ao autor real facilmente comprováveis ${ }^{40}$ e a um diário ao qual ele tem um acesso indevido em qualquer esfera que não a literária. Como procede o leitor? Como fica o pacto de leitura quando a intimidade oferecida pelo narrador ganha o suplemento de verdade do paratexto abaixo, que apresenta o livro em sua contracapa?

[36] Das Confissões de Rousseau às autobiografias que se seguiram; de Em Busca do Tempo Perdido, de Proust, a W ou a memória da infância, de Perec; das vanguardas modernistas e do Oulipo às narrativas ficcionalizadas oriundas do Holocausto, o debate do testemunho, a retomada do sujeito.

[37] Bem mais, inclusive, do que era o leitor do século 19, que receberia a autobiografia de Sthendal analisada por Porter e já estava habituado a separar verdade e ficção, jornalismo e prosa literária.

[38] Ao explicar o pacto autobiográfico de Lejeune (1975), Galle afirma que é a exata identidade entre autor, narrador e protagonista que estabelece o pacto, "uma vez que o autobiógrafo as insinua e o leitor as aceita como assunções subjacentes da sua leitura” (p. 68). Tal pacto inexistiria em uma ficção, mesmo autobiográfica. Para Genette (apud GALLE), a autoficção origina um pacto em que cabe ao leitor a investigação das contradições, pois o texto classificado paratextualmente de autoficção o instiga a tornar-se investigador do estatuto da obra. É comum a relação entre autor e narrador não ser suficientemente evidente para delimitar a presença de ficção ou não ficção. Essa relação "não seria sempre um sinal nítido e deveria ser deduzida da totalidade de (outras) características da narrativa" (p. 77).

[39] "A característica dominante da autoficção seria a intencional indiscernibilidade do pacto, que impossibilita que o leitor leia o texto exclusivamente sob uma ou outra modalidade e que implanta uma ambiguidade indelével no texto" (p. 110)

[40] Na página 66, termina um trecho do que seria um e-mail ao advogado da ex-mulher da seguinte maneira: "Um abraço, Ricardo Lísias". Na página 78, lê-se: "Quando o medo de ter enlouquecido ficou muito forte, parei em um sinal vermelho e repeti o meu nome. Ricardo Lísias. O meu nome é Ricardo Lísias.” E, a partir da página 150, aparecem, até o fim do livro, 11 fotos, em muitas das quais se vê uma criança com os traços físicos do autor, cuja foto oficial recente figura na orelha do livro. 
Agosto de 2011. Casado há quatro meses, o narrador de Divórcio encontra acidentalmente o diário da esposa em que, entre outras coisas, ela escreve: O Ricardo é patético, qualquer criança teria vergonha de ter um pai desse. Casei com um homem que não viveu. "Depois de quatro dias sem dormir, achei que tivesse morrido", ele desabafa. A partir de então, descreve seu desmoronamento e a tentativa de compreender o que o levou ao ponto crítico. A literatura e os treinos de corrida cada vez mais intensos servem para que alguma lucidez retorne à sua vida. Mas nem sempre é possível explicar friamente o que ocorreu, dar ordem aos sentimentos conflitantes, à dor e à obsessão, ao desejo de esquecer. É isso o que torna Divórcio um romance sem paralelos. Num fluxo emocionante, numa reconstrução ficcional da memória, o autor ultrapassa os limites da autoficção e alcança um novo terreno, em que a literatura - a literatura combativa, desafiadora - tem a última palavra (negritos meus).

Que pacto se estabelece entre autor, narrador e leitor? Que "contrato de leitura" (1975, p. 8) surge quando o leitor tem já no paratexto não só a biografia do autor (com bibliografia idêntica à do narrador), mas a rubrica "romance" aliada à "autoficção"? ${ }^{41}$. Se o paratexto deixa claro que o autor, por meio de uma "reconstrução ficcional da memória" (real), "ultrapassa os limites da autoficção" (a ficcionalização da vida real) e "alcança novo um terreno" - terreno de uma literatura "combativa", leia-se, de vingança -, a ficcionalidade que se via garantida pela (rubrica romance) ou os procedimentos de narração (o discurso indireto livre) fica embotada, suspensa, no caso de Divórcio.

Se já não basta apelar para a suposta ficcionalidade inalienável da literatura para garantir a definição de um contrato de leitura, o que dizer do pacto estabelecido entre autor e leitor nas condições descritas, onde todo esforço para aproximar vida pessoal/real/biografia do autor (e logo o estatuto de verdade, de testemunho, de real do texto) da recepção do leitor é realizado sem pudores, dentro (formalmente, no relato em primeira pessoa, e também, rematicamente, nas referências concretas e verificáveis à realidade) e fora do texto (os paratextos), para se ater apenas ao volume físico do livro?

Pois o autor-narrador-personagem ganha outros discursos que cercam o leitor. A partir da décima página, qualquer leitor curioso com o tipo

[41] Assim, há o impacto de tal filiação à autoficção, gênero epistemologicamente incerto, eticamente problemático, localizado numa fronteira movediça que flerta sempre com o escândalo e o sofrimento real. 
de registro que está lendo (esse que Genette imagina), se ainda ignorante do tipo de produção do autor em mãos, faria uma pesquisa na internet. $E$ Ricardo Lísias é um autor extremamente midiático. Algo raro no Brasil, dá entrevistas frequentes à televisão, a jornais, a sites. Publica contos em revistas. E tem uma farta conta no Facebook, onde republica todo esse material, textos de seu fanzine e publicações textos de cunho privado.

Como diz Galle, (p. 112) citando Zipfel, uma "função adicional" da autoficção seria a "superação da fronteira entre obra literária e biografia do autor, ou seja a fronteira entre arte e vida". Autores como Robbe-Grillet, por exemplo, prestar-se-iam a "esse modelo de uma confluência das duas esferas, da realidade do autor histórico e dos textos produzidos por ele", processo facilitado hoje pela presença dos autores na mídia ${ }^{42}$. No caso de Divórcio, a engenharia discursiva em torno da obra tem outro nível, com direito a circular- libelo, contos publicados em revista abordando a mesma história do romance por vir e entrevistas nas quais explica a especificidade biográfica da obra ${ }^{43}$.

Em todos os textos há os mesmos temas: o diário, o divórcio, a feitura da literatura a partir do trauma. Poder-se-ia chamar esses documentos de paratextuais (ou epitextos, diria Genette), na medida em que fazem parte de forma integral não só do alcance e do tom da fruição/leitura mas da forma da própria construção do livro enquanto obra ou, ainda mais, em relação ao estatuto ficcional dos trechos do suposto diário encontrados no livro Divórcio? Ou seriam tais epitextos "espaços escriturais", como pensa Galíndez-Jorge (2009, p. 84), onde a escritura romanesca acontece como método em prática, projeto (literário) em andamento - e, sobretudo,

[42] Diz Galle: "Comparando a proporção entre o tempo que o público assiste às manifestações extraliterárias de um autor e o tempo que se aplica para ler seus livros, a imagem midiática do autor começa a dominar a imagem formada a partir da obra. A autoficção pode enfrentar esse problema com uma estratégia ofensiva: apresentar uma obra que desde já não permite mais distinguir entre vida real e ficção, entre obra e realidade" (pp. 112-113).

[43] Lísias preparou o terreno. Fez circular por e-mail e via redes sociais um texto no qual expunha uma intimação extrajudicial enviada pelo advogado da ex-esposa (real) com ameaças à publicação por parte dele de informações de um suposto diário que teria sido escrito por ela e encontrado (e copiado) por ele, além de um libelo em favor de sua liberdade criativa e da literatura em si (e de si). Nesse documento, ele conta a mesma história do romance, mas como sendo verdade, como sendo a vida dele, o autor. Lê-se ali, por exemplo, a seguinte frase: "Xeroquei o diário para me resguardar". Pouco depois, Lísias publicou o primeiro conto na revista Piauí, no qual escrevia sobre o diário e sobre ter começado a correr para suportar o divórcio. Lê-se na página 77: "Procurei os manuscristos do conto Divórcio, que eu publicaria três meses depois, e percebi que os primeiros esboços datam do sábado." O diálogo estabelecido entre romance e outros textos da vida real é indelével. Em seguida, publicou uma versão do que seria um primeiro capítulo do livro: fez cópias em casa e distribuiu a jornalistas e amigos. A versão foi copiada em $p d f$ e distribuída pela internet. Em seguida, publicou outro conto de teor similar na mesma revista. Com a publicidade alcançada por essas etapas, deu uma série de entrevistas à imprensa, sedenta por informações sobre o livro sendo escrito. Meses depois saía Divórcio, com críticas nos jornais e vendas acima da média 
visto sua publicação, como parte de uma ampla performance literária ${ }^{44}$ ? Creio que ambas. $\mathrm{O}$ que se vê nos textos mencionados é um processo de criação literária que trabalha em duas frentes concomitantes e interdependentes, a literária-ficcional e a biográfica-real.

Ao fazer circular entre jornalistas e leitores textos que tratam das circunstâncias objetivas e verificáveis de sua vida privada (e, logo, da ex-mulher), Lísias liga vida e obra de forma inextricável. O diário (real) pode ou não ser o mesmo diário (ficcional) cujos trechos existem no romance: seu estatuto textual fica eternamente em suspenso, vagando entre o espaço da obra, o diálogo midiático a interpelação judicial e o mundo real. Para o leitor, o efeito dessa rede textual é o de uma performance autoral inalienável, que permeará o romance e a voz atribuída a esse narrador-protagonista.

Quando o narrador menciona livros que teria escrito (e foram escritos pelo autor), ou personagens dessas mesmas obras; quando divide momentos de vida com o autor (ter sido enxadrista ou corrido na São Silvestre, fatos que povoam as reportagens a seu respeito); quando decide chamar de $[\mathrm{X}]$ alguns dos personagens e pelo nome outros, o que demonstra um compromisso de veracidade referencial - 0 efeito de presenciar o testemunho de uma biografia real impregna o leitor. E não com uma história verossímil que ele esquece por momentos ser fictícia, mas como uma história que ele sente ser real.

Analisadas ambas as obras de Sterne e Lísias, podemos compará-las de forma mais detida. Tanto em TS como em Divórcio, a primeira pessoa oferece ao leitor uma conversa íntima sobre a vida do narrador, que abre o coração, sem rodeios, criando um pacto com o leitor, como se dissesse: a partir de agora, contarei como a minha vida se deu em tal período. Você será meu ombro amigo, minha testemunha. Mas há uma diferença sustentada a partir dos paratextos/ epitextos. Enquanto em TS o leitor pode esquecer, segundo a variação da gasta noção de "suspensão temporária da descrença", que o que lê é ficcional, peça imaginativa artisticamente

[44] Para Klinger (2007, p. 25), a autofiç̧ão poderia ser vista como uma escrita da performance, na medida em que supõe "uma dramatização de si" um processo de construção do outro na figura do eu "que supõe, da mesma maneira que ocorre no palco teatral, um sujeito duplo, ao mesmo tempo real e fictício, pessoa (ator) e personagem” (idem). 
produzida ${ }^{45}$, o leitor da autoficção pode esquecer que o que lê é real, podendo fruir a ficção como suplemento de verdade eticamente indecifrável. Pois, quando alfinetado por referências da realidade da narrativa, pode fuçar na intimidade alheia, não só do autor-narrador-personagem como na de terceiros, sem precisar desculpar-se por isso: o suprassumo da experiência estética da autoficção jaz nessa suspensão ética atrelada à suspensão estatutária do texto.

Como sustenta Galle (p.148), nós, leitores contemporâneos, nos acostumamos a diferenciar "textos que fazem referência à realidade compartilhada e aqueles que são produto da imaginação do autor e que apenas nos permitem participar durante um tempo limitado do jogo imaginativo sem que os 'fatos' propostos tenham consequências para nossas ações diárias". Quando o texto expõe a suspensão estatutária, como faz Divórcio, dando ao leitor a chance de se imiscuir na vida íntima de alguém que pode ser real e ter sua vida exposta/distorcida ao público, as "consequências" tornam-se claras ${ }^{46}$.

Não é o caso do leitor defrontado com uma obra ficcional anunciada paratextualmente como sendo de natureza discursiva real, como seria o caso dos livros de Defoe, ou com uma obra formalmente autobiográfica permeada por intertextos reais e um grau de autocomentário e narração em primeira pessoa que bagunçaria as percepções de um leitor do século 18, como TS, e nem apenas com uma obra que usa elementos biográficos e autobiográficos reais travestidos de ficção e anunciados simplesmente como tal, mas com um romance que faz da suspensão de seu estatuto textual, entre verdade e ficção, calcado na relação escancarada com homonímias, referências reais e epitextos a ele ligados, marcados pelo signo saboroso do testemunho. De início, o tom íntimo de Lísias se assemelha a Shandy. Mas as páginas seguintes oferecem chaves de compreensão do livro, sendo que a principal delas é a que define a obra: sua indefinição estatutária transformada em jogo ético-estético.

[45] Se os códigos do que viria a ser o realismo ainda estavam longe de ser senso-comum, o estatuto discursivo do romance tampouco se aferrava a uma noção de ficcionalidade clara, como vimos.

[46] Supor que a questão ética não norteia a recepção de um livro que deliberadamente embaralha seu estatuto seja secundária à ficção parece ser ingenuidade. Diz Meira (2013): "Se déssemos por certa a inexistência do diário, a máquina das questões éticas se desligaria, ou se tornaria mais débil. Afinal, por que preocupar-se com personagens de ficção? Mas a literatura de Ricardo Lísias vive exatamente do embaralhamento e da vertigem que nos toma sempre que nos sabemos demasiado próximos da realidade. Aí estão os limites que a ética deve explorar, mas está também o alcance político da ficção, que interpela vivos e mortos, para não deixá-los jamais à vontade". 
Vários elementos sustentam a impressão. Por exemplo, a relação que se instaura entre os trechos do diário, italizados, repetidos, imbuídos de sua suposta função pragmática (ou contexto pragmático) inicial e também de um caráter proibitivo (o íntimo roubado, não autorizado, e por isso de fruição eticamente duvidosa, a não ser que se terceirize toda a culpa para o autor/narrador) e o texto principal: a partir da metade do livro, eles se mesclam e as frases do diário surgem repetidas, não italizadas, em meio à voz do narrador. Os trechos seguintes dão mais força aos fragmentos do diário, ao definir (ainda que, a princípio, apenas no simples nível da diegese) um estatuto ficcional e outro referencial aos trechos do diário nos contos que alimentaram o romance:

Quando as pessoas souberem quem de fato é essa mulher, vão no mínimo querer cuidar de mim. Para isso, planejei colocar entre os parágrafos do novo conto trechos refeitos (mas com o mesmo sentido) do diário" (p. 164).

Resolvi me certificar e duas outras pessoas, entre as tantas que estavam inundando a minha vida de fofoca, foram atrás da informação e de fato voltaram dizendo que ela tinha mesmo jogado o diário fora. Não tive dúvidas, então: descartei a minha redação e no conto "Meus três Marcelos", simplesmente reproduzi alguns trechos do diário da minha ex-mulher" (p. 171).

Uma relação dialógica se instaura, assim, entre dois níveis de registro: as "notas autobiográficas" que o narrador diz retomar em sua pesquisa por memória para escrever o romance e o relato em tom de testemunho/relato autobiográfico final narrado no livro. Quando diz: "Ontem, quando fui preparar esse trecho (escrevo logo depois de acordar, mas deixo tudo arranjado no dia anterior), reli uma parte do que escrevi naquele período" (p. 49), o grau de intimidade do leitor com a obra sendo escrita lembra os trechos de TS nos quais Shandy parece dividir com o leitor (e com supostos críticos, às vezes em diatribes hipotéticas) a criação e as decisões sobre a economia forma da obra.

Quando Lísias escreve: "Estou redigindo a primeira versão desse capítulo em maio de 2012" (p. 120), lembra TS, quando Shandy diz: "And here am I sitting, this 12th day of August, 1766, in a purple jerkin and yellow pair of slippers, without either wig or cap on, a most tragicomical completion of his prediction, 'That I should neither think, nor act like any other man's 
child, upon that very account" (p. 546) ${ }^{47}$. Lísias, depois do último trecho, diz: "O capítulo fracassou. Meu plano inicial era lembrar tudo o que vivi de bom com minha ex-mulher para entender porque resolvi me casar" (p. 131). Não podemos deixar de pensar nos capítulos dos capítulos de TS (p. 252), seguido da defesa de dois capítulos sobre "o que se passou descendo um par de escadas" (p. 253).

O narrador usa ainda marcadores espaço-temporais fartos: frases como "Estou escrevendo onze meses depois de ter saído de casa" (idem) e menções sobre onde e como está escrevendo qual trecho, dando a noção exata de um percurso de escrita que representa uma experiência de vida real, como faz Shandy em TS. Isso sem falar da relação, tipicamente realista (com o suplemento da história recente) entre fatos históricos (e não apenas biográficos) comprováveis ${ }^{48}$ e da relação, como já se disse aqui, entre textos ficcionais publicados a partir do divórcio e sobre ele (no caso, dois contos na revista Piau1 ${ }^{49}$. Pois não é nova a técnica de mostrar o livro sendo escrito em presença do leitor, nem mesmo a provocação à realidade do leitor ${ }^{50}$. O que muda é a suspensão completa do estatuto ficcional elevar o efeito dessa intimidade ao infinito.

Interessante notar que tais referências tecem ainda um discurso paralelo, de cunho autobiográfico pseudo-intraficcional, que só corrobora a percepção pelo leitor de um autor real que se entrega e de uma intimidade sem limites, uma parceria, um pacto. Como se o leitor pudesse acompanhar a formação biográfica paulatina do escritor-narrador, seu diário de desvios não ficcionais, sua projeção em migalhas de realidade entrelaçados na ficção. A história de vida se complementa. As referências

[47] Além de remeter à presença física do narrador e à sua disposição em escancarar a economia formal da obra ao leitor, com ele dividindo a produção e a chave de compreensão da obra em devir, tal trecho deixa claro como o protagonista da história é o narrador-escritor (e, por extensão, a priori, essa instância narrativa do escritor que tanto que confunde com o autor). Assim, para LADEN (2014), é a situação de enunciação que ganha vida, em detrimento da autobiografia strictu sensu (p. 130).

[48] Por exemplo, quando descreve a participação da ex-mulher cobrindo o festival de Cannes: "Minha ex-mulher estava na plateia da entrevista em que Lars von Trier, a despeito de apresentar Melancolia, disse ser meio nazista e entender Hitler. A situação é mais embaraçosa porque em momento algum ele aparenta ter perdido inteiramente o controle. Ao menos no início, antes de tudo virar uma bola de neve, o cineasta parece debochar de alguma coisa. Assisti à entrevista dezenas de vezes. A última foi ontem, quando esquematizei esse fragmento" (p. 112, grifos meus)

[49] Por exemplo, como no trecho que segue: “Quando faltavam duas semanas para terminar o curso de contos e 'Meus três Marcelos' já estava na metade, finalmente o primeiro texto que escrevi sobre tudo isso, 'Divórcio', foi publicado (p. 165).

[50] Como prova o narrador de TS quando escreve, após defender seu direito de reescrever quantos capítulos quiser: “...for never do I hit upon any invention or device which tendeth to the furtherance of good writing, but I instantly make it public; willing that all mankind should write as well as myself" (p. 561). 
se repetem ${ }^{51}$. Assim, chegamos ao que Burgelin define como "autocomentador", instância narrativa formada pela superposição de instâncias: o personagem, o narrador, o autor e o comentador, "entre as quais se introduz um pouco de jogo, sabiamente mantido" (p. 64).

Por um lado, o narrador homônimo e biograficamente similar ao autor comenta a própria obra. "Divórcio é um livro repetitivo" (p. 173), diz o narrador, para quem o livro uma verdadeira "profissão de fé" (p. 184) ${ }^{52}$. Há aqui a defesa de que a autoficção não é só uma escrita do testemunho, mas uma ficção com propósito além do eu, voltada para o ataque a qualquer formalismo, à defesa intransigente da liberdade ontologicamente assegurada à escrita literária. O comentário sobre a literatura que pilha a realidade em busca da vingança que recoloque uma instância ética à vida acaba se tornando, além de técnica com efeito estético, uma defesa da literatura como campo ${ }^{53}$.

Seguindo algo da tradição shandyana, o narrador elenca tais erros (o tema da maratona sumiu na segunda parte do livro, assim como as memórias do avô; a conceituação de classe média brasileira arrivista ficou fraca; o livro parece descontínuo, etc.). E, num ato-falho que ressuscita alguma luz para a definição do pacto de leitura:

"Estou com medo de que, na verdade, tenha sido um problema do autor. Depois de um ano de tratamento intenso, em que depositei todas as minhas energias na recuperação do choque que sofri ao ler o diário da minha ex-mulher, não consigo me organizar inteiramente. Mas estou

[51] Afinal, desde a página 16 de O Céu dos Suicidas (obra citada em Divórcio como do narrador) o leitor sabe que o narrador em primeira pessoa se chama Ricardo. Não tenho como analisar a constância do narrador de Sterne, mesmo sabendo que os sermões de Yorick e os vários volumes de Shandy guardam para o leitor uma identificação óbvia. Mas o efeito de leitura de obras diversas com uma mesma voz narrativa, mesmo sem o fenômeno da homonímia, vale a menção.

[52] A partir da página 184, o grau de comentário aumenta, ganha ares de libelo ético e estético sobre a vida e a arte: "A falência da ética, inteiramente soterrada pelo interesse financeiro, causa ditaduras tão violentas quanto as antigas. Como elas aparecem acompanhadas por uma variação estranha da palavra liberdade, ficam mais difíceis de ser identificadas. Vou dar um exemplo: e a minha liberdade, depois de ter testemunhado e vivido tudo isso sobre o meu corpo nu, de escrever um livro e ser o mais claro e direto possível? Acredito que a arte deva desafiar qualquer tipo de poder. Divórcio é a minha profissão de fé contra essas neoditaduras. Sempre me irritaram os romancistas que pretensamente 'retratariam o ponto de vista do outro'. Aqueles que dão espaço para posições contrárias apresentam vários pontos de vista e relativizam tudo. Parte da teoria literária os tomou como grandes artistas justamente por conta disso: eles não acreditam apenas no próprio ponto de vista e suas personagens e situações sempre mostram o outro lado da moeda (idem, grifos meus)".

[53] Vide os exemplos abaixo: "Divórcio não é um livro de jornalismo, não tem fontes, não usa offs, as fotos são de arquivos familiares e o autor do livro, responsável por todas as linhas, é Ricardo Lísias" (p. 196). "Não reconheço a inverossimilhança como um defeito de Divórcio. Mas hoje, treze meses depois de começar a escrevê-lo e portanto, dezessete de ter lido o diário, encontro alguns problemas no livro. Já os pressentia durante a redação e deixei o décimo terceiro capítulo para comentá-lo" (p. 199). 
bem melhor: se tivesse redigido as linhas anteriores há oito meses, teria que sair para uma hora de corrida intensa" (p. 203).

Da mesma forma que Shandy em TS (mas sem seu wit ou "subacid humour'), o $13^{\circ}$ capítulo segue como uma reflexão sobre os defeitos da obra, com o narrador contando histórias que esqueceu ou lamentando as que não conseguiu adicionar, e comentando os problemas que vê no livro, como se o comentário da obra pudesse definir seu lugar na literatura e na recepção do leitor e, por meio de um mea-culpa atrás do outro, antecipar respostas a quaisquer perguntas ${ }^{54}$. E conclui: "O fato é que Divórcio não recuperou apenas o meu equilíbrio emocional. O livro e as corridas me trouxeram uma pele nova e agora quero me tornar uma pessoa melhor" (p. 210). Verter em narrativa literária uma experiência de vida era a função dessa literatura engajada em si mesma ${ }^{55}$. E quando o leitor parece finalmente satisfeito com a estratégia do livro, Lísias, o autocomentador, parece tentar jogar água em tudo e relativizar o libelo.

Parece que estava nervoso no fragmento anterior. Ao contrário, planejei tudo para que, em um crescendo de indignação, o narrador chegasse à conclusão final. Eu e ele nos descolamos. Fiz até uma pequenina tabela com as características do narrador que Divórcio foi constituindo enquanto eu apaziguava meu trauma. Ela vai ter pouco uso, porém: no próximo capítulo, o narrador sai para que Ricardo Lísias volte à cena (p. 217, negritos meus).

Mas existe o eu. Mesmo que tente uma última instância para desvencilhar-se do jogo estatutário que provocou, dirigindo-se a um suposto juiz e explicando o procedimento que assumiu no romance ${ }^{56}$, já não é

[54] Vide os excertos a seguir: "Tentei escrever sobre a relação fraturada com o meu pai no capítulo três, depois no sete e no oito. Não consegui encaixar o fragmento em nenhum deles" (p. 206). "Na última leitura achei alguns parágrafos mal escritos e vários confusos. Não sei o que o editor vai achar deles "(p. 213). "Durante o auge da minha raiva, fui injusto com os "jornalistas". Generalizei para toda a categoria o comportamento de um grupo específico" (p. 215)

[55] Vide os excertos: "O livro vai chegando ao fim e, mesmo sem ter conseguido contornar todos os defeitos que enxergo nele, sinto-me forte. Se o meu objetivo inicial era deixar para trás todo o mal-estar que senti ao ler o diário, Divórcio é um romance bem-sucedido” (p. 212). "Estou curioso com o que os leitores vão achar. Provavelmente, alguns acabem julgando um absurdo a exposição que fiz da minha ex-mulher. A eles, terei uma resposta pronta: é uma personagem. Para ser sincero, acredito nisso" (p. 214).

[56] "O que faz então com que Divórcio seja um romance? Em primeiro lugar, Excelência, é normal hoje em dia que os autores misturem à trama ficcional elementos da realidade. Depois há um narrador visivelmente criado e diferente do autor” (pp, 217-218). 
mais possível separar artificialmente o que, durante mais de 200 páginas, caminhou (ou correu) indissociável ${ }^{57}$. Até que o trecho seguinte jogue a pá de cal sobre a definição estatutária do texto:

Ainda que eu me contradiga em outro lugar desse texto e no que eu possa eventualmente dizer sobre essa merda toda em que me joguei, o diário que reproduzo aqui é sem nenhuma diferença o mesmo que xeroquei antes de sair de casa. Aliás, não há uma palavra de ficção nesse romance (p. 172).

Trata-se de um jogo, ainda mais agressivo do que o perpetrado por Shandy em TS, a autoficção de Divórcio. A relação entre esse autor-narrador-protagonista e o leitor reflete, penso, um jogo entre o narcisista engajado na aventura de delimitar os limites possíveis da literatura que brota de si e o voyeur que assiste à tentativa de tatear as fronteiras do aceitável sem envolver-se eticamente com ela. O que atrai o último é a emoção contida exclusivamente no singular, essa "energia" que o contamina e eletriza ${ }^{58}$.

Como sugere Burgelin, "a autoficção favorece uma confusão entre criação e comentário sem equivalente" (idem). Casos como o de TS, onde o narrador comenta a obra sendo escrita, sua publicação e recepção também teciam para o leitor da época uma rede discursiva pautada pela indissociação do "dentro" e do "fora" da obra ${ }^{59}$, e de seu estatuto. A autoficção, porém, leva a indecisão ao extremo. Porque, se a estrutura narrativa, como em TS, é a do testemunho confessional, em primeira pessoa, aqui ela é potencializada pela permeabilidade do estatuto, não

[57] O narrador ainda lança pistas que servem como chaves de compreensão do estatuto do diário e da narrativa em torno dele. Uma hora, ele diz: "Tudo isso é inverossímil. Cabe apenas em um romance: a explicação para o surto que Lars von Trier teve no Festival de Cannes de 2011 veio parar em uma gaveta da minha casa” (p. 113). E, pouco depois, como se jogasse a última pedra sobre o pacto referencial-ficcional e, ao mesmo tempo, ajudasse a se proteger de um futuro processo judicial: "Não estou tratando de uma pessoa em particular. Minha ex-mulher não existe: é um personagem de romance" (p.128).

[58] Chama a atenção de Jeanelle (2011, p.55) que os romances biográficos travestidos de memórias apócrifas que fizeram sucesso no século 19 na França fossem recebidos pelo público como confissões disfarçadas, assim como, segundo Davis, dava-se na Inglaterra com as baladas e os primeiros romances.

[59] A discussão sobre a impossibilidade de estabelecer um "dentro" e um "fora" da literatura é antiga e equivocada. Quando o romance contém uma narrativa que dialoga com a performance autoral midiática, em outros discursos que tecem juntos uma supra-performance indissociável para um leitor contemporâneo (que não está fruindo a leitura em frente à lareira de um lar burguês francês do século 19, mas ao lado de um celular, no tablet ou computador, onde alguns cliques o lançam num manancial de narrativas de vida e de arte sobre o livro e o autor), todo o texto que leve a assinatura e se liga às referências narrativas contidas no romance, passa, a meu ver, a ser constitutivo desse literário complexo. 
só pela homonímia, mas pelo suporte paratextual erguido antes da publicação do livro, parte do complexo arquitetônico autoficcional sem o qual o livro perde seu suplemento de intimidade.

O caso de Lísias é claro: o passo-a-passo da feitura do livro, com publicações de pedaços da obra e comentários sobre sua feitura (assim como de sua vida, presentes em entrevistas e na circular), se mescla às críticas (na imprensa e na academia) feitas sobre o livro e às entrevistas que o autor deu à imprensa - fundamental para a completude ou o alcance máximo do efeito da autoficção. "A maneira com que qualquer leitor interpreta o meu livro é de responsabilidade dele próprio", disse o autor em uma das entrevistas publicadas perto do lançamento de Divórcio $^{60}$.

Assim, Ricardo Lísias, autor-narrador-personagem que comenta sua vida na escrita passa também a comentar sua escrita dentro e fora dela, escrita que assim ganha vida própria, numa metanarração ad infinitum. $\mathrm{O}$ livro, a vida do escritor e a ontologia da literatura se tornam indissociáveis para o leitor. Com um suplemento institucional em jogo, o escritor-crítico-midiático surge como sucedâneo da impossibilidade de atestar a origem e os estatutos discursivos na vida e na arte. A literatura parece se confundir deliberadamente com sua história, deontologia e teoria: a obra problematiza a vida do escritor e sua vida problematiza a obra, num ciclo eterno de indecidibilidade focado no leitor. A "crônica da vida das letras", como diz Burgelin (p. 63), se confunde com a crítica da obra e a teoria por trás do método, por meio da fala do autocomentador no romance e nos lugares de fala institucionais, tendo o leitor como único juiz do estatuto.

Penso, por isso, poder vislumbrar nessa literatura rotulada de autoficção um novo senso comum, um outro lugar de intimidade com códigos culturais reconhecíveis ao leitor e que, paradoxalmente, parece subjazer exatamente na indefinição ético-estética - ou quiçá na crença de que quem tudo diz e tudo pode dizer é o autor e não uma instância imaginativa criada por uma experiência estética do âmbito calculado da arte. $\mathrm{O}$ leitor da autoficção lê, assim, segundo a proposta presente, o que essa instância autoral-narrativa, íntima e verdadeira, que a ele se liga quase fisicamente, oferece. Pois parece jazer justamente na intimidade desse novo código o prazer dessa leitura.

[60] "Não tenho nenhum interesse por nada que não seja literatura (...) Como eu disse, cada leitor é livre para fazer a própria leitura. A literatura - e de novo a arte de maneira mais ampla - não é capaz de reproduzir a 'realidade'. Assim, nenhum romance 'expõe' a vida de seu autor ou de qualquer outra pessoa, mas sim cria personagens e situações ficcionais (...) Não creio que a literatura se refira em nenhum grau à 'vida' de seu autor ou de quaisquer outras pessoas". Obtido em: http://g1.globo.com/platb/maquinadeescrever/tag/divorcio e acessado em 12 de dezembro de 2015 
Consumir ficção como se fosse experiência privada (ou o oposto, consumir uma experiência privada como se fosse uma ficção de tipo realista) - ou, de forma mais exata, consumir esse compósito ética e esteticamente inclassificável como um registro qualquer, ontologicamente indefinível, no seio de uma operação estética mais ampla, calcada em discursos paralelos antes classificados como "extraliterário", refletiria uma dimensão cultural específica da literatura ocidental dos últimos $a{ }^{61}$, que estabelece, como diz Galle (2011, p. 111), "um novo paradigma de escrita autobiográfica" ${ }^{62}$. Num paralelo arriscado (pelo anacronismo), vejo a autoficção recolocar o mesmo tipo de discussão sobre os limites da ficção que observamos, com Davis, desde o século 17 na Europa limites que, suspensos, servem para fazer pensar o literário socialmente, devolvendo-lhe uma dimensão crítica renovada. Se questionarmos o que a autoficção, como projeto literário e gênero específico, diz da sociedade atual, penso que a resposta jaz no entrecruzamento entre ética e estética em seu paroxismo de indeterminação.

Uma obra como Divórcio ensejaria a anulação da distinção possível do estatuto entre o ficcional e o referencial, e logo da natureza ontológica da dimensão de verdade do sujeito que escreve e se escreve. Em busca da determinação semântica de quem fala, o leitor entraria no jogo dessa "máquina produtora de mitos" (p.24), como sugere Klinger (2007). Em vez de apagar a figura do autor que escreve a história que ganha vida por si só, apanágio do realismo visto pela teoria (pós-)estruturalista, a autoficção convocaria o leitor para um enfrentamento direto, não apenas com a figura do autor, mas com o texto e seu processo de escrita, revestidos de uma "ilusão da presença", como pensa Arfuch (2005, p.42) - fundamental para ativar essa nova dinâmica, na qual o leitor se vê com a tarefa de

[61] Diz Schwartz (2013, p. 84): "Essa mistura de ficção e autobiografia é uma das características mais marcantes do romance contemporâneo. Basta pensar em uma lista muito reduzida dentre os inúmeros escritores de gerações diferentes que nos últimos sessenta anos fazem essa mescla de maneiras bastante distintas, além dos três já mencionados acima: Primo Levi, Thomas Bernhard, W.G. Sebald, Georges Perec, Giuseppe Berto, Saul Bellow, Imre Kertész, Claudio Magris, Ernesto Vila-Matas, António Lobo Antunes, Julian Barnes, Art Spiegelman, Paul Auster, Bernardo Carvalho, Michel Laub, Ricardo Lísias".

[62] Vale pensar que "o termo autoficção designa hoje um lugar de incerteza estética que é também ume espaço de reflexão", como afirma Gasparini (2008, p.7). Com a retomada do sujeito como estratégia narrativa, o romance volta à baila como produto cultural relevante. 
decidir a chave interpretativa do texto, apreender seus mecanismos e por meio deles "cogitar" sobre o estatuto final da escrita literária ${ }^{63}$.

Em sua conclusão sobre a ascensão do romance na Inglaterra, Mckeon viu na dialética da dupla negação entre epistemologias do discurso de verdade a chave para entender como o romance o gênero se formou e como se entendia a distinção entre verdade e ficção na época. $O$ mesmo parece se dar com a autoficção, mas em outro grau, o do paroxismo. Serve, de qualquer forma, para discutir o papel social do romance. Se ele é de fato um gênero que essencialmente se discute como possibilidade estética, ética e política, poderíamos ver as questões epistemológicas que surgem do debate trazido pelo impacto da autoficção ${ }^{64}$ como um eco reatualizado dos debates trazidos à tona pelos romances do século 18. Além da (in)distinção entre fato e ficção, tem-se o jogo enunciativo entre autor, narrador e personagem, a busca pela autoridade da voz e toda dimensão ético-estética trazida pela exacerbação da performance que envolve outros sujeitos, vivos, e todo o jogo de sadismo e voyerismo aí encerrado.

É quando o narrador Ricardo Lísias passa a ecoar Tristam Shandy em sua crítica ao romance (autobiográfico, mas não só) travestida de sátira paródica. Lísias é um Shandy sem o wit e os brios protestantes de não jogar alguém na fogueira pública apenas para ver, esteticamente, o que surge do fogo. Mas, tão bem como ele, reflete na forma da literatura o que sua sociedade, seu contexto cultural, sua filosofia tentarão dar conta nos próximos anos: como trabalhar vida e realidade, fato e ficção, na literatura. I

[63] Assim, "a autoficção só faz sentido se lida como show, como espetáculo, ou como gesto" (p. 26), diz Klinger. Acrescentaríamos a noção de jogo: a autofiç̧ão é efetiva e atrai o leitor, alcança uma dimensão literária específica, digamos, se é capaz de convocar o leitor para um enfrentamento, um jogo que precisa suspender as certezas sobre o próprio registro de leitura. A condição da existência do jogo se daria numa exacerbação da noção de performance, quando o mecanismo artístico que essa põe em xeque passa necessariamente pelo testemunho da impossibilidade de dar o testemunho da escrita.

[64] No Brasil, tal discussão é ainda crua e recente, mas na França, na Alemanha, na Espanha e nos EUA, o debate na academia e na imprensa sobre os limites entre verdade e ficção e sobre o uso do real pelo ficcional, alcançou já um patamar sólido. Ver, por exemplo: BURGELIN, Claude, GRELL, Isabelle. Autofiction(s), actes du colloque de Cerisy-la-Salle. Lyon: PUL, 2010. 
WILLIAN VIEIRA - Doutorando do programa de Estudos Linguísticos, Literários e Tradutológicos em Francês da Universidade de São Paulo - USP. São Paulo, SP, Brasil. vieira.will@usp.br. Esse artigo foi produzido para a conclusão do curso Caminhos do Romance: deslocamentos e descentramentos, ministrado pela Profa. Sandra G. T. Vasconcelos no segundo semestre de 2015 


\section{REFERÊNCIAS}

BURGELIN, Claude, GRELL, Isabelle. Autofiction(s), actes du colloque de Cerisyla-Salle. Lyon: PUL, 2010.

COHN, Dorrit. The distinction of fiction. Baltimore: Johns Hopkins University Press, 1999.

COLONNA, V. Autofiction et autres mythomanies littéraires. Auch: Tristram, 2004.

DAVIS, Jennard J. Factual Fictions. Nova York: Columbia University Press, 1983.

DOUBROVSKY, S. Fils. Paris: Galilée, 1977.

FOREST Philippe. Christine Angot. Les Petits. IN: Art Press, 2011.

GALÍNDEZ-JORGE, Verónica. Fogos de Artifício: Flaubert e a Escritura. Cotia: Ateliê Editorial, 2009

GALLE, H. O gênero autobiográfico: possibilidade(s), particularidades e interfaces. 2011. 281 f. Tese (Livre Docência) - Departamento de Letras Modernas, Universidade de São Paulo, São Paulo, 2011.

GASPARINI, Philippe. Autofiction - Une aventure du langage. Paris: Seuil, Poétique, 2008.

GENETTE, Gerard. Fiction et diction. Paris: Seuil, 1991.

HUNTER, J. PAUL. "Response as Reformation: "Tristram Shandy" and the Art of Interruption”. NOVEL: A Forum on Fiction, Vol. 4, No. 2 (Winter, 1971).

JEANNELLE, Jean-Louis; VIOLLET, Catherine (dir). Genèse et autofiction. Louvain-la-Neuve: Academia-Bruylant, 2007.

KLINGER, Diana E. Escritas de si, escritas do outro: o retorno do autor e a virada etnográfica. Rio de Janeiro: 7 Letras, 2007.

LEJEUNE, P. Le pacte autobiographique. Paris: Éditions du Seuil, 1975.

LÍSIAS, R. Divórcio. Rio de Janeiro: Alfaguara, 2013. 
MCKEON, Michael. The origins of the English novel, 1600 -1740. The Johns Hopkins University Press, 2000.

MEIRA, Pedro. "Como falar a verdade? A ética da ficção em Divórcio, de Ricardo Lísias". Celeuma, 2013.

MORINI, Massimiliano. "The poetic of disengagement: Jane Austen and echoic irony”. Language and literature, 2010.

PORTER, Dennis. "Fictions of Art and Life: Tristram Shandy and Henry Brulard". MLN, Vol. 91, No. 6, Comparative Literature (Dec., 1976).

RICKS, Christopher. Introduction. Em: STERNE, Laurence. The Life and Opinions of Tristam Shandy, Gentleman. Londres: Penguin Classics, 2003.

RICOUER, Paul. Tempo e narrativa (tomos I, // e III). São Paulo: Papirus, 1994. O si mesmo como outro. São Paulo: WMFMartins Fontes, 2010.

SAMOYAULT, Tiphaine, L'intertextualité. Paris: Armand Colin, 2010.

SCHMITT, Arnaud. Je réel / Je fictif, Au-delà d'une confusion postmoderne. Presses universitaires du Mirail, coll. essais de littérature CRIBLES, 2010.

SCHWARTZ, Adriano. "A Tendência autobiográfica do romance contemporâneo: Coetzee, Roth e Piglia”. Adriano Schwartz. Novos estudos CEBRAP [online]. 2013, n.95.

SINDING, Michael. "Genre in Autobiography and Early First-Person Novels". SubStance \#122, Vol. 39, no. 2, 2010.

STERNE, Laurence. The Life and Opinions of Tristam Shandy, Gentleman. Londres: Penguin Classics, 2003.

WILLIAMS, Jeffrey. "Narrative of Narrative (Tristram Shandy)”. MLN, Vol. 105, No. 5, Comparative Literature (Dec., 1990). 